\title{
Sosialisasi Hepatitis B dengan Menggunakan Video Edukasi pada Kelompok Remaja di Kelurahan Bener Kecamatan Tegalrejo Kota Yogyakarta
}

\section{Francisca Romana Sri Supadmi*1, Nur'Aini Purnamaningsih ${ }^{2}$}

1,2Prodi Teknologi Bank Darah (D-3), Universitas Jenderal Achmad Yani Yogyakarta, Indonesia *e-mail: francisca.ro74@gmail.com ${ }^{1}$, nurainipurnamaningsih21@gmail.com $^{2}$

\begin{abstract}
Abstrak
Remaja merupakan target calon pendonor darah lestari dimana seorang remaja yang sehat dan beresiko rendah, berpotensi untuk menjadi pendonor darah rutin setiap dua sampai tiga bulan sekali hingga usia maksimal seseorang dapat melakukan donasi darah yaitu sekitar 65 tahun atau lebih atas pertimbangan dokter. Pendonor darah dikatakan beresiko rendah jika memiliki gaya hidup yang sehat, aktif menjaga kesehatannya, bebas dari infeksi menular seperti HIV, Hepatitis B, Hepatitis C, Sifilis, Malaria, dan infeksi lainnya yang lewat transfusi darah. Pada masa remaja, terdapat perubahan gaya hidup dari anak-anak menuju dewasa, sehingga seringkali mengalami perubahan gaya hidup yang menyebabkan gangguan kesehatannya. Kelurahan Bener termasuk wilayah perkotaan dengan populasi pendudukberagam dan tingkat kepadatan tinggi, sangat rentan terhadap penularan infeksi Hepatitis B. Sosialisasi Hepatitis B dengan menggunakan video edukasi pada remaja telah dilaksanakan di Kelurahan Bener pada tanggal 21 November 2021, dengan diikuti 25 remaja perwakilan dari 17 RT, terdiri dari 11 perempuan dan 14 laki-laki. Kegiatan dilakukan dengan menyesuaikan dengan protocol kesehatan yang ketat. Hasil sosialisasi terdapat peningkatan tingkat pengetahuan peserta semula rata-rata nilainya 50,4 menjadi 64 yang dibuktikan dengan pretest dan postest. Hal ini membuktikan bahwa sosialisasi dengan video edukasi menjadi media yang efektif untuk kegiatan edukasi kepada masyarakat khususnya remaja.
\end{abstract}

Kata kunci: Donasi Darah, Donor Darah, HBV, Hepatitis B

\begin{abstract}
Adolescents are the target of potential sustainable blood donors where a healthy, low-risk teenager has the potential to become a regular blood donor every two to three months until the maximum age a person can donate blood is around 65 years or older at the discretion of a doctor. Blood donors are said to be at low risk if they have a healthy lifestyle, actively maintain their health, are free from infectious infections such as HIV, Hepatitis B, Hepatitis C, Syphilis, Malaria, and other infections through blood transfusions. During adolescence, there are lifestyle changes from children to adults, so they often experience lifestyle changes that cause health problems. Bener Village is an urban area with a diverse population and high density, very vulnerable to transmission of Hepatitis B infection. Hepatitis B socialization using educational videos for adolescents has been carried out in Bener Village on November 21, 2021, with 25 youth representatives from 17 RTs participating, consisting of 11 women and 14 men. Activities are carried out in accordance with strict health protocols. The results of the socialization there was an increase in the level of knowledge of the participants from an average value of 50.4 to 64 as evidenced by the pretest and Post-test. This proves that socialization with educational videos is an effective medium for educational activities to the community, especially teenagers.
\end{abstract}

Keywords: Blood Donation, Blood Donation, HBV, Hepatitis B

\section{PENDAHULUAN}

Pemenuhan kecukupan kebutuhan darah atau komponen darah yang aman, bermanfaat, mudah diakses, dalam jumlah yang memadahi, serta terjangkau oleh masyarakat diperlukan sebagai satu upaya kesehatan dalam rangka penyembuhan penyakit dan pemulihan kesehatan. Pemenuhan stok darah atau komponen darah sebagaimana dimaksud, diperoleh dari pendonor darah yang sehat, beresiko rendah, dan memenuhi kriteria seleksi pendonor (Peraturan Menteri Kesehatan Nomor 91 Tahun 2015 Tentang Standar Pelayanan Transfusi Darah, 2015).

Remaja merupakan target calon pendonor darah lestari dimana seorang remaja yang sehat dan beresiko rendah, berpotensi untuk menjadi pendonor darah rutin setiap dua sampai tiga bulan sekali hingga usia maksimal seseorangdapat melakukan donasi darah yaitu sekitar 65 tahun atau lebih atas pertimbangan dokter. Hal ini sering disebut dengan istilah pendonor lestari 
(Peraturan Menteri Kesehatan Nomor 91 Tahun 2015 Tentang Standar Pelayanan Transfusi Darah, 2015).

Pendonor darah dikatakan beresiko rendah jika memiliki gaya hidup yang sehat, aktif menjaga kesehatannya, bebas dari infeksi menular sepertiHIV, Hepatitis B, Hepatitis C, Sifilis, Malaria, dan infeksi lainnya yang lewat transfusi darah. Agar dapat menjadi pendonor yang beresiko rendah, dapat diupayakan sedini mungkin sejak masih anak-anak ataupun remaja. Pada masa remaja, seseorang mengalami perubahan gaya hidup dari anak-anak menuju dewasa, sehingga seringkali mengalami perubahan gaya hidup bersama-sama komunitasnya, yang dapat menyebabkan gangguan kesehatannya. Sebagai contoh budaya begadang, minum-minuman beralkohol, merokok, dan lain- lainnya. Hal ini sagat berpotensi menyebabkan gangguan kesehatan terutama kesehatan hati.

Gangguan kesehatan organ hati sering disebut dengan Hepatitis ini selainberhubungan dengan gaya hidup, infeksi hepatitis dapat disebabkan oleh karenainfeksi virus. Infeksi virus yang dapat menyebabkan kerusakan hati diantanya disebabkan oleh Virus Hepatitis A, B, C, D, dan E serta virus yang tidak termasuk dalam kategori tersebut (Balitbangkes, 2014). Dari bermacam virus hepatitis yang menular lewat darah dan menjadi perhatian sehingga harus dilakukan skrining pada darah pendonor adalah Virus Hepatitis B (Peraturan Menteri Kesehatan Nomor 91 Tahun 2015 Tentang Standar Pelayanan Transfusi Darah, 2015).

Virus Hepatitis B (VHB) ditularkan melalui rute parenteral, yang berarti di luar saluran pencernaan. Sarana utama penularan VHB adalah melalui darah yaitu penerima transfusi darah yang terinfeksi VHB, pasien hemodialisa, pekerja kesehatan atau terpapar darah, kontak dengan darah yang terinfeksi pada jarum hipodermik. Virus hepatitis B ditemukan di cairan tubuh yang memiliki konsentrasi virus hepatitis B yang tinggi seperti semen, sekret servikovaginal, saliva, dan cairan tubuh lainnya sehingga cara transmisi hepatitis B lainnya yaitu melalui transmisi seksual. Cara transmisi lainnyamelalui penetrasi jaringan (perkutan) atau permukosa yaitu alatalat yang tercemar virus hepatitis B seperti sisir, pisau cukur, alat makan, sikat gigi, tato, akupuntur, tindik, alat kedokteran, dan lainnya. Cara transmisi lainnya yaitu transmisi vertical maternal-neonatal, maternal-infant, akan tetapi tidak ada bukti penyebaran fekal-oral (Supadmi \& Purnamaningsih, 2019).

Semua Virus Hepatitis termasuk Hepatitis B seringkali muncul sebagai kejadian luar biasa. Infeksi ini sangat berhubungan dengan perilaku hidup bersih dan sehat, bersifat akut dan sembuh dengan baik, namun dapat menjadi kronik bahkan menjadi sirosis dan karsinoma (Balitbangkes, 2014).

Hepatitis B hingga saat ini masih menjadi permasalahan kesehatan utama di dunia. WHO memperkirakan bahwa 296 juta orang hidup dengan infeksi hepatitis B kronis pada tahun 2019, dengan 1,5 juta infeksi baru setiap tahun. Pada tahun 2019, hepatitis B diperkirakan menyebabkan 820.000 kematian, sebagian besar disebabkan oleh sirosis dan karsinoma hepatoseluler (kanker hati primer). Beban infeksi hepatitis B tertinggi di Wilayah Pasifik Barat dan Wilayah Afrika, di mana masing-masing 116 juta dan 81 juta orang terinfeksi kronis. Enam puluh juta orang terinfeksi di wilayah MediteraniaTimur, 18 juta di wilayah Asia Tenggara, 14 juta di wilayah Eropa dan 5 juta diWilayah Amerika (World Health Organization, 2021).

Indonesia merupakan negara dengan endemisitas tinggi terhadap Hepatitis B terbesar kedua di negara South East Asian Reagion (SEAR) setelah Myanmar. Berdasarkan hasil Riset Kesehatan dasar (Riskesdas), studi dan uji saring terhadap darah pendonor diperkirakan dari 100 juta orang Indonesia, 10 diantaranya telah terinfeksi Hepatitis B dan C. Sehingga diperkirakan terdapat 28 juta penduduk Indonesia teringeksi Hepatitis B. Tingginya angka kesakitan akibat Hepatitis B berdampak terhadap masalah kesehatan diantaranyamempengaruhi produktivitas, umur harapan hidup, dan tentunya dampak ekonomi dan sosial. Hasil analisis situasi menunjukkan, gambaran prevalensi Hepatitis B pada remaja berdasarkan pada hasil riskesdas tahun 2013, terdapat 1.1\% penderita Hepatitis B pada kelompok umur 15-24 tahun. Hasil ini merupakan urutan ketiga setelah kelompok umur 65-74 tahun (1.4\%) dan kelompok umur 25-34 tahun (1.3\%) (Balitbangkes, 2014). Berdasarkan hasil penelitian Naully dan Romlah (2018) dari 100 orang remaja di kota Cimahi, terdapat 2 orang (2\%) yang terinfeksi hepatitis B (Naully \& Romlah, 2018). 
Kalurahan Bener merupakan salah satu wilayah termasuk kecamatan Tegalrejo, kotamadya Yogyakarta, Daerah Istimewa Yogyakarta. Batas-batas wilayah Tegalrejo ditunjukkan sebelah utara ditunjukkan oleh batas desa Trihanggo, Gamping, Sleman dan Kelurahan Kricak, Tegalrejo, Yogyakarta. Sebelah Timur ditunjukkan oleh batas Kelurahan Kricak Tegalrejo, Yogyakarta dan Kelurahan Bumijo, Jetis, Yogyakarta. Sedangkan batas Selatan ditunjukkan oleh Kelurahan Tegalrejo, Kecamatan Tegalrejo, Yogyakarta dan sebelah Barat ditunjukkan oleh batas Desa Ngestiharjo, Kasihan, Bantul. Kelurahan Bener termasuk wilayah perkotaan dengan populasi penduduk yang beragam dan tingkat kepadatan penduduk yang tinggi sehingga sangat rentan dengan penularan infeksi. Selain hal tersebut Kelurahan Bener dengan jumlah populasi yang banyak tersebut, berpotensi untuk menjadi sumber pendonor darah di kota Yogyakarta. Agar masyarakat Kelurahan Bener menjadi masyarakat yang beresiko rendah terhadap infeksi menular maka sangat penting adanya edukasi terhadap masyarakat khususnya remaja agar menjadi calon pendonor darah yang sehat dan lestari.

\section{METODE}

Sasaran kegiatan ini adalah remaja di Kelurahan Bener Kecamatan Tegalrejo Kota Yogyakarta berjumlah 50 orang, namun dikarenakan pandemic, pihak kelurahan menyarankan peserta maksimal 25 orang sesuai kapasitas Gedung dengan protokol kesehatan. Kegiatan telah dilaksanakan padatanggal 21 November 2021 pukul 11.00 - 16.00 WIB. Pelaksanaan kegiatan terdiri atas tiga kegiatan meliputi tahap persiapan, pelaksanaan, dan tahap akhir kegiatan.

\subsection{Tahap Persiapan}

Tahapan persiapan meliputi studi pendahuluan dan koordinasi dengan Lurah Bener untuk mendapatkan informasi dan gambaran kegiatan, serta kegiatan pembuatan Media Edukasi dan Publikasi terkait kegiatan PKM yang dilaksanakan oleh tim pengabdi yang terdiri dari dosen dan mahasiswa yang terlibat berupa flyer, poster, banner, dan video edukasi.

\subsection{Tahap Pelaksanaan}

Pelaksanaan kegiatan pemberian Edukasi terkait Hepatitis B dilaksanakan tanggal 21 Nonember 2021 pukul 11.00 - 16.00 WIB. Tahapan kegiatan terdiri dari pretest, Sosialisasi, dan Post-test. Kegiatan pretest dilakukan dengan media googleform. Jumlah soal yang digunakan sebanyak 10 soal berbentuk multiplechoice. Kegiatan sosialisasi dilakukan dengan metode ceramah dan menyaksikan tayangan video bersama secara luring. Setelah penayangan video akan dilanjutkan dengan tanya jawab. Kegiatan Post-test akan dilakukan dengan media googleform. Jumlah soal yang digunakan untuk menggali tingkat pengetahuan peserta sosiaslisasi sebanyak 10 soal berbentuk multiplechoice.

\subsection{Tahap Akhir}

Tahap akhir kegiatan meliputi analisis data hasil sosialisasi dengan menggunakan analisis deskriptif, pembuatan laporan kegiatan pengabdian kepada masyarakat, dan publikasi kegiatan.

\section{HASIL DAN PEMBAHASAN}

Pemenuhan kecukupan kebutuhan darah atau komponen darah yang aman, bermanfaat, mudah diakses, dalam jumlah yang memadahi, serta terjangkau oleh masyarakat diperlukan sebagai satu upaya kesehatan dalam rangka penyembuhan penyakit dan pemulihan kesehatan. Pemenuhan stok darah atau komponen darah diperoleh dari pendonor darah yang sehat, beresiko rendah, dan memenuhi kriteria seleksi pendonor.

Remaja merupakan sasaran utama kegiatan rekrutmen calon pendonor darah lestari dimana seorang remaja yang sehat dan beresiko rendah, berpotensi untuk menjadi pendonor darah rutin setiap dua sampai tiga bulan sekali hingga usia sekitar 65 tahun atau lebih atas 
pertimbangan dokter. Kelurahan Bener sebagai salah satu keluarahan di Kecamatan Tegalrejo, Kotamadya Yogyakarta, sangat berpotensi menjadi kantong pendonor darah di Kota Yogyakarta. Populasi penduduk yang terbilang padat dan dengan pluralitas yang tinggi, tentu beresiko terhadap berbagai infeksi salah satunya Hepatitis B.

\subsection{Data Demografi Peserta}

Peserta sosialisasi Hepatitis B adalah remaja Kelurahan Bener yang semula direncanakan 50 peserta, namun karena pandemi dan harus menerapkan protokol kesehatan dengan menjaga jarak, maka kegiatan sosialisasi diwakili oleh 25 remaja yang terdiri dari laki-laki 14 orang dan perempuan 11 orang. Dari 25 remaja tersebut, berdasarkan tingkat pendidikan, terdapat dua remaja sedang menempuh pendidikan di perguruan tinggi dan berstatus sebagai mahasiswa dan 23 remaja berstatus sebagai pelajar baik SLTP maupun SLTA. Peserta merupakan perwakilan dari 17 Rukun Tetangga (RT) yang terdistribusi dari 4 Rukun Warga (RW).

\subsection{Hasil Pretest dan Post-test}

Hasil pretest dan Post-test disajikan pada Tabel 1 berikut.

Tabel 1. Hasil Pretest dan Post-test

\begin{tabular}{ccc}
\hline No & Score Post-test & Score Pretest \\
\hline 1 & 40 & 80 \\
2 & 30 & 30 \\
3 & 40 & 40 \\
4 & 50 & 50 \\
5 & 40 & 80 \\
6 & 30 & 30 \\
7 & 80 & 80 \\
8 & 60 & 100 \\
9 & 70 & 70 \\
10 & 60 & 90 \\
11 & 60 & 60 \\
12 & 70 & 70 \\
13 & 30 & 30 \\
14 & 80 & 80 \\
15 & 30 & 30 \\
16 & 40 & 40 \\
17 & 50 & 50 \\
18 & 40 & 80 \\
19 & 30 & 30 \\
20 & 40 & 80 \\
21 & 60 & 100 \\
22 & 70 & 70 \\
23 & 60 & 90 \\
24 & 60 & 60 \\
25 & 40 & 80 \\
\hline MIN & 30 & 30 \\
MAX & 80 & 100 \\
AVERAGE & 50,4 & 64 \\
\hline Nilai & 20 & 8 \\
$<70$ & 5 & 3 \\
$70-89$ & 0 & \\
\hline
\end{tabular}

Berdasarkan Tabel 1 dapat dijelaskan, bahwa nilai tertinggi dari hasil pretest adalah 80 dan nilai pretest terendah adalah 30. Jumlah peserta yang mendapatkan nilai $70-89$ sebanyak 5 
orang (20\%) dan peserta yang mendapatkan nilai kurang dari 70 sebanyak 20 orang (80\%). Nilai rata-rata pretest adalah 50.4. Hal ini menunjukkan bahwa mayoritas tingkat pemahaman peserta tentang Hepatitis B, masih kurang. Gambaran hasil pretest seperti pada gambar 1 berikut.

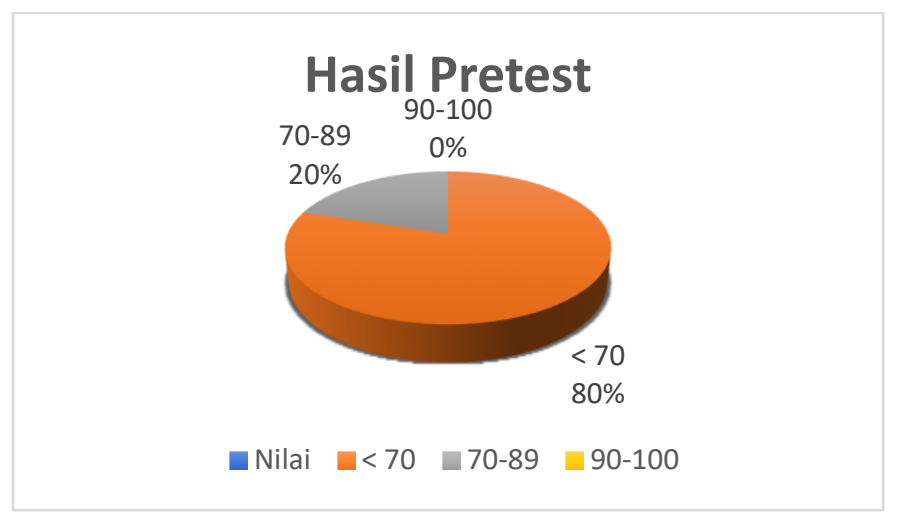

Gambar 1. Hasil Pretest

Berdasarkan Tabel 1 dapat dijelaskan, bahwa nilai tertinggi dari hasil post-test adalah 100 dan nilai post-test terendah adalah 30. Jumlah peserta yang mendapatkan nilai baik sekali yaitu antara 90-100 terdapat $17 \%$ yang semula $0 \%$. Peserta yang mendapatkan nilai antara $70-89$ sebanyak $39 \%$ yang semula $20 \%$ dan peserta yang mendapatkan nilai kurang dari 70 sebanyak $44 \%$ yang sebelumnya $80 \%$. Nilai rata-rata post-test adalah 64 . Gambaran hasil post-test seperti pada gambar berikut.

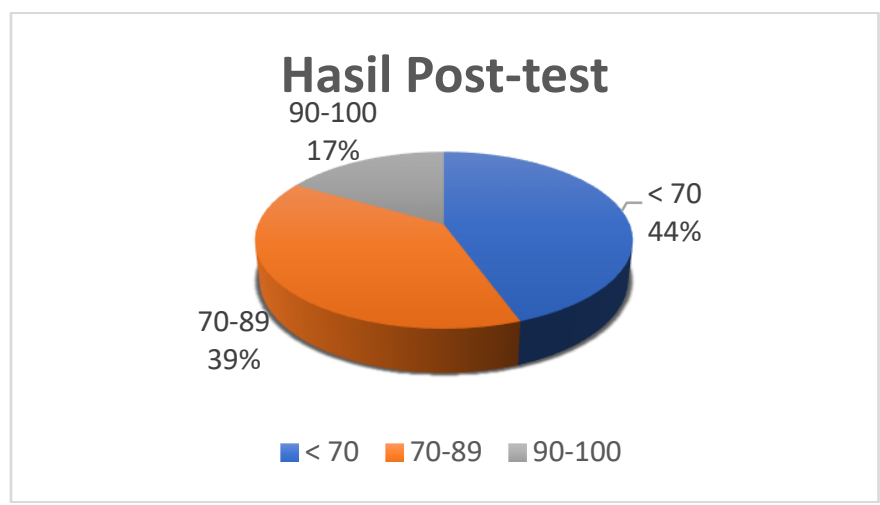

Gambar 2. Hasil Post-test

Berdasarkan pada hasil pretest dan post-test dapat dijelaskan bahwa terdapat perbedaan tingkat pengetahuan peserta, menjadi lebih baik. Hal ini dibuktikan dengan adanya peningkatan nilai rata-rata yang semula 50.4 menjadi 64. Luaran dari kegiatan pengabdian ini adalah terjadinya perubahan tatanan masyarakat terkait dengan pengetahuan terhadap Hepatitis $B$, mulai dari pengertiannya, penyebabnya, cara penularannya, cara pencegahannya, dan bagaimana langkah yang ditempuh jika pernah mendapatkan riwayat Hepatitis B, terutama bagi calon pendonor darah. Dengan peningkatan pengetahuan tersebut, diharapkan remaja Kelurahan Bener akan menerapkan upaya-upaya pencegahan terhadap Hepatitis B, sehingga semakin layak menjadi calon pendonor darah regular.

\section{KESIMPULAN}

Dari hasil pretest diketahui bahwa tingkat pemahaman remaja Kelurahan Bener terhadap Hepatitis B mayoritas masih rendah (80\%). Setelah dilakukan sosialisasi Hepatitis B dengan media video edukasi, tingkat pemahaman peserta meningkat, dibuktikan dengan peningkatan nilai post-test dari rata-rata 50.4 menjadi 64 . 


\section{UCAPAN TERIMA KASIH}

Penulis mengucapkan terima kasih kepada Fakultas Kesehatan Universitas Jenderal Achmad Yani Yogyakarta dan Kelurahan Bener yang telah memberi dukungan terhadap pengabdian ini.

\section{DAFTAR PUSTAKA}

Balitbangkes. (2014). Situasi dan Analisis Hepatitis di Indonesia. In Pusdatin Kemenkes RI (pp. 18).

Peraturan Menteri Kesehatan Nomor 91 Tahun 2015 Tentang Standar Pelayanan Transfusi Darah, (2015). https://doi.org/10.3923/ijss.2017.32.38

Naully, P. G., \& Romlah, S. (2018). Prevalensi HIV dan HBV pada Kalangan Remaja. Jurnal Kesehatan, 9(2), 280. https://doi.org/10.26630/jk.v9i2.908

Supadmi, F. R. S., \& Purnamaningsih, N. (2019). Infeksi Menular Lewat Transfusi Darah (IMLTD) (S.Utami, Ed.; 1st ed.). Kemenkes RI. Pusat Pendidikan Sumber Daya Manusia Kesehatan. Badan Pengembangan dan Pemberdayaan Sumber Daya Manusia Kesehatan Edisi Tahun 2019.

World Health Organization. (2021). Hepatitis B. https://www.who.int/news-room/factsheets/detail/hepatitis-b 